\title{
Taking research with its roots: restructuring schools in the Brazilian landless workers' movement upon the principles of a political ecology of education
}

\author{
David Meek \\ University of Alabama, USA $^{1}$
}

\begin{abstract}
How does education mediate the relationship between the co-production of environmental knowledge, and the social reproduction of an alternative society? This article draws upon a political ecology of education framework to analyze how schools advance alternative land management strategies and forms of environmental knowledge. Schools catering to grassroots movements can actualize their emancipatory objectives by institutionalizing hybridized conceptions of educational space-time. This article focuses on a vocational high school in a settlement of the Brazilian Landless Workers' Movement. It analyzes a document known as a 'political pedagogical project' (PPP) which details the identity of the school and how it sees itself as a tool for social and environmental justice. Through an analysis of this PPP, my article explores how the school seeks to educate students to critically reflect upon the relationships between political economic processes and landscape change. The PPP also encourages students to be active participants in the development of a regional agroecological science, and cooperative material relations. From a political ecology of education perspective, activist schools are important sites for the coproduction of environmental knowledge and material relations. They have the potential to help students learn critically about the linkages between power, political economy, and land management.
\end{abstract}

Keywords: Landless Workers Movement; political ecology of education; hybridity, political pedagogical project, agroecology

\section{Résumé}

Comment l'éducation peut servir de médiateur de la relation entre la co-production de connaissances sur l'environnement, et de la reproduction sociale d'une société alternative? Cet article se fonde sur un cadre de l'écologie politique de l'éducation pour analyser comment les écoles progresser les stratégies de gestion des terres, et les formes de la connaissance de l'environnement. Des écoles pour les mouvements populaires peuvent actualiser leurs objectifs d'émancipation, en institutionnalisant conceptions hybrides de l'éducation l'espace-temps. Cet article se concentre sur un lycée professionnel dans un campement du Mouvement des travailleurs sans terre brésiliens (Movimento dos Trabalhadores Sem Terra). Il analyse un document connu comme un "projet pédagogique politique» (PPP) qui détaille l'identité de l'école et comment il se considère comme un outil pour la justice sociale et environnementale. Grâce à une analyse de ce PPP, l'article explore la façon dont l'école cherche à éduquer les étudiants à une réflexion critique sur les relations entre les processus économiques et politiques et l'évolution du paysage. Le PPP encourage également les élèves à être des participants actifs dans le développement d'une science agroécologique régionale et les relations de coopération matérielles. D'un point de vue de l'écologie politique de l'éducation, les écoles activistes sont des sites importants pour la co-production de connaissances environnementales et du relations matériels. Ils ont le potentiel d'aider les élèves à apprendre de façon critique sur les liens entre le pouvoir, l'économie politique et la gestion des terres.

Mots-clés: Mouvement des Travailleurs Sans Terre; écologie politique de l'éducation; hybridité, projet pédagogique politique, l'agroécologie

\section{Resumen}

¿De qué manera sirve la educación para mediar entre la coproducción del conocimiento ambiental y la reproducción social de una sociedad alternativa? Este articulo utiliza un marco analítico de la ecología

\footnotetext{
${ }^{1}$ Dr. David Meek, Instructor, Department of Anthropology, University of Alabama, Tuscaloosa, AL 35476, USA. Email: ddmeek "at" ua.edu. Thankyou to the referees and editors, and for funding NSF grant BCS \#1060888, the Fulbright Program, and the Social Science Research Council. This is the fourth article in James R. Veteto and Joshua Lockyer (eds.) 2015. "Towards a political ecology of applied anthropology", Special Section of the Journal of Political Ecology 22: 357-465.
} 
política de la educación para analizar como escuelas promuevan estrategias alternativas para el manejo de tierras y formas alternativas de conocimiento ambiental. Escuelas que sirven a los movimientos sociales pueden realizar sus objetivos emancipadores a través de la institucionalización de conceptos híbridos del espacio-tiempo educacional. Este artículo se enfoca en una preparatoria vocacional en una comunidad formada por el Movimiento de Trabajadores Rurales Sin Tierra (MST) en Brasil. Analiza a un documento conocido como un ?proyecto pedagógico político? (PPP) que discute con detalles la identidad de la escuela y su papel de arma para conseguir la justicia socioambiental. La escuela busca educar a sus estudiantes para que entiendan y critiquen a los vínculos entre procesos económico-políticos y cambios en el paisaje. Promueve la participación activa en el desarrollo de una ciencia agroecológica regional y relaciones sociales cooperativas. Desde la perspectiva de la ecología política de la educación, escuelas activistas como esta pueden ayudar a los alumnos a entender los vínculos entre poder, economía política, y manejo de la tierra.

Palabras Clave: Movimiento de Trabajadores Rurales sin Tierra; ecología política de la educación; hibridez; proyecto político pedagógico, agroecología.

\section{Resumo}

Como é que a educação mediar a relação entre a co-produção do conhecimento ambiental, e a reprodução social de uma sociedade alternativa? Este artigo baseia-se em uma teoria de ecologia política da educação para analisar como as escolas avançar estratégias e formas de conhecimento ambiental e sistemas de manejo de terras alternativas. Escolas de que pertence os movimentos populares podem realizar seus objetivos emancipatórios, institucionalizando concepções de hibridizaram educacional espaço-tempo. Este artigo concentra-se em uma escola profissional em um assentamento do Movimento dos Trabalhadores Rurais Sem Terra do Brasil. Ele analisa um documento conhecido como um "projeto político pedagógico" (PPP), que detalha a identidade da escola e como ele vê a si mesma como uma ferramenta para a justiça social e ambiental. Através de uma análise dessa PPP, meu artigo explora como a escola visa educar os alunos a refletir criticamente sobre as relações entre os processos econômicos e políticos e de mudança da paisagem. O PPP também incentiva os alunos a serem participantes activos no desenvolvimento de uma ciência agroecológica regional e as relações de cooperação. A partir de uma perspectiva de ecologia política de educação, escolas do movimento são encontrados para ser locais importantes para a coprodução de conhecimento ambiental e relações materiais. Eles têm o potencial de ajudar os alunos a aprender criticamente sobre as relações entre poder, economia política e gestão da terra.

Palavaras Chaves: O Movimento dos Trabalhadores Rurais Sem Terra; ecología política do educação; projeto político pedagógico; agroecología

\section{Introduction}

A central concern within political ecology is the politics of environmental knowledge (Biersack and Greenberg 2006; Bryant 1997; Forsyth 2003; Robbins 2004; Zimmerer and Basset 2003). "Knowing nature", for political ecologists, "is a complex, multiple, and highly political process" (Goldman and Turner 2011: 1). ${ }^{2}$ Ideas are never neutral and always "either reinforce or challenge existing social and economic arrangements" (Schmink and Wood 1987: 51). Material struggles over resources are also struggles over meaning (Jarosz 1996; Peluso 1992). Contested knowledge is sometimes separated from material resources, focusing instead on the construction of scientific knowledge claims (Demerrit 2001; Forsyth 1996). While political ecologists have historically explored the politics of knowledge, education is a surprisingly novel arena for analysis.

Recent scholarship has sought to redress this absence by developing a political ecology of education. Preliminary efforts define the political ecology of education as a lens for analyzing the interrelationships between political economy, education, environmental knowledge and behaviors, and ecological contexts (Meek 2014, 2015a,b). The political ecology of education (PEoE) framework treats education as an umbrella concept that encompasses a broad range of pedagogical opportunities-from tacit to formal learning (Baker et al. 2002; Livingstone 2006; Marsick et al. 2009). This perspective holds that education is not politically, economically, and ecologically neutral, but instead a central arena for the

\footnotetext{
2 Political ecologists' treatment of environmental knowledge has been significantly influenced through interdiscinplinary conversations with science and technology studies (See Goldman, Nadasdy, and Turner 2011).
} 
production, dissemination, and contestation of environmental knowledge at various interconnected scales (Cox 1998; McKenzie 2012; Smith 1992). By focusing on how political economy links environmental learning and behaviors, this lens affords the ability to explore education's effect on access to and control over natural resources, land management practices, and students' conceptions of nature-society interrelationships (Meek 2014, 2015a,b). The PEoE is a fertile arena for applied work, because education's purview applies to the entire cycle of knowledge production, dissemination, consumption, and application. By focusing on education, political ecologists have the ability to become involved in the transformation of schools into sites of socio-environmental justice (Peet and Watts 2004).

Formal education has the potential to structure society, conceptions of nature, and material relations in opposing ways. Educational institutions can either reproduce the hegemonic society, and its relations to "nature" as something external, or can help advance counter-hegemonic conceptions of naturesociety interrelations. For example, activist educators can amend state curricula to inculcate alternative conceptions of material relations, and valorize subaltern forms of environmental knowledge. In this article I explore how radical schools structure students' understanding of the links between political economic systems and environmental change, as well as both schools' and students' involvement in the coproduction of environmental knowledge and alternative social structures.

Schools are inherently hybrid phenomena, which Donna Haraway (1991) would call "cyborgs", or Bruno Latour (1993) would refer to as "quasi-objects." Adapting Eric Swyngedouw's (1999) argument, schools can be seen as "hybrid, part social/part natural-yet deeply historical and thus produced, objects/subjects," which "are intermediaries that embody and express nature and society and weave networks of liminal spaces" (p.445, italics in original). A school is not simply the edifice where formal education happens, but is inherently part social/part natural. Schools are a network of interrelations between environmental histories, ecological processes, spatiotemporal contexts, economic resources, curricula, teaching styles, and political ideology. Schools and their administrators invest considerable resources in projecting a school's essence as explicitly, and singularly, social (Collins 2009). I argue that this is, however, a façade as schools are hybrid phenomena. Learning how schools can become restructured in line with their hybridity is an applied project for political ecologists of education.

I present a case study in this article of a Brazilian vocational high school known as the Federal Institute of Pará, Rural Campus of Marabá (Instituto Federal do Pará-Campus Rural do Marabá or IFPACRMB). This school has strong links to the Brazilian Landless Workers' Movement (O Movimento dos Trabalhadores Rurais Sem Terra or MST). ${ }^{3}$ Through a review of the literature, I first advance the argument that education reproduces society, conceptions of material relations, and co-production of environmental knowledge. I then explore how the MST uses education to articulate a new vision of material production and nature-society relations. This is followed by a site description of the Federal Institute of Pará, Rural Campus of Marabá (IFPA-CRMB). The remainder of the article analyzes the IFPA-CRMB's Political and Pedagogical Project (Projeto Político Pedagógico or PPP), which is an institutional plan for creating a transformative educational institution.

\section{Hybridized schools and the reproduction of socionature}

What is the relationship between education, the production of environmental knowledge, and the organization of society? This section advances a theoretical argument that addresses this larger question, which is subsequently supported by an analysis of the IFPA-CRMB's political and pedagogical project (PPP). The overarching argument is as follows. Education reproduces hegemonic society and its constitutive means of environmental knowledge production (Gough and Whitehouse 2003). Education also has the potential to advance alternative orderings of society and processes of environmental knowledge production. The division of time and space is pivotal to education's role in both social

\footnotetext{
${ }^{3}$ In addition to the MST, the IFPA-CRMB has linkages to other rural syndicate movements, such as the Federation of Agricultural Workers (Federação dos Trabalhadores na Agricultura or FETAGRI), and the Federation of Family Farmers (Federação dos Trabalhadores na Agricultura Familiar or FETRAF). This article focuses on the MST in part because it was one of the most active movement participants in the origination of the IFPA-CRMB, and continues to play a formative role through its participation on the school's governing council. In addition, as I will describe later, the IFPA-CRMB is located in an MST settlement. Despite all of this interaction with the MST, the IFPA-CRMB is not an exclusively MST school. An analysis of the role of education and agroecology within this movement is, however, necessary to understand their ideological presence in the school.
} 
reproduction and knowledge production. Education scholars and practitioners traditionally treat knowledge as produced solely in the temporal and spatial confines of schools (Chandler 2009; Nespor 2002). However, schools are hybrid phenomena, which are dialectically produced through the dialogue and contradiction of times and spaces that are both inside and outside of the traditional school setting. Restructuring schools and their curricula to acknowledge this hybridity is one way to transform educational institutions into instruments of political ecology.

Education exists in a complicated relation with the reproduction of society. Education reproduces the dominant societal structures, norms, and career pathways (Althusser 1971; Anyon 1981; Apple 1979; Bourdieu and Passeron 1977; Bowles and Gintis 1976; Willis 1977; Noguera 2009). ${ }^{4}$ Education implicitly prepares working class students for working class jobs, and students in general learn to uncritically accept the basic structure of society (Carnoy and Levin 1985). ${ }^{5}$ Aside from the formal curriculum, social reproduction also occurs through the implicit, or hidden, curriculum (Dudley 1977; Apple and King 1977; Crockenberg and Bryant 1978; Inlay 2003), which consists of the "unacknowledged, either intentional or unintended, pedagogical content that promulgates and maintains knowledge and appropriate behavior" (Meek 2011: 169). Abu-Lughod's (1998, 2005) exploration of how Egyptian television serials are pedagogical tools used to produce specific subjects and imagined communities exemplify the analysis of the implicit curriculum (Anderson 1983). Education's hidden curriculum holds the potential to naturalize students' understanding of productive relations, nature, and scientific knowledge by presenting history, geography, and economic systems in an uncritical manner.

The concept of co-production provides a lens to explore how education structures the creation of environmental knowledge. Following Jasanoff (2004:19), a key proponent of the concept, the "coproductionist account.... seeks to understand how particular states of knowledge are arrived at and held in place, or abandoned." This perspective analyzes how science and technology mediate understandings of nature, and how the politics of knowledge order society. It explores the relation between scientific methods and instruments that reconfigure nature, and other social devices, such as laws, financial incentives, media representations, and interest groups that reorder society. Co-productionist accounts ask how particular sites of knowledge production, as diverse as research laboratories, hospitals, and legal proceedings, create stability around emerging technoscientific phenomena, such as climate change. One of the key questions for scholars of environmental knowledge co-production is "what are the principal pathways by which such co-production occurs?" (Jasanoff 2004: 18). I will show that education and schools are respectively important pathways and instruments for the co-production of environmental knowledge because they are where conceptions of what constitutes scientific methodologies and knowledge are continually inscribed, thus affecting how students create boundaries between the social and natural. I will present data subsequently that demonstrate how a radical school trains its students to develop a regionally specific science of agroecology, which in itself helps to promulgate new forms of social organization. The co-production of environmental knowledge and forms of cooperative production are interrelated and tied to the students' lived realities. In this case study, these forms of co-production are mediated by the spatial and temporal characteristics of the school environment.

The way that schools structure students' schedules and the spaces in which learning occurs influences the reproduction of society. As Harvey writes, "a particular way of representing space and time guides spatial and temporal practices which in turn secure the social order" (1990: 419). Education strictly delineates space and time by creating structured spatial settings and time schedules that reify conceptions of knowledge as disciplinary and discrete. ${ }^{6}$ Studies consistently highlight the important role that schools' spatiotemporal context plays in mediating learning (Chandler 2009; Comber and Nixon 2008; Nespor 2002; Piro 2008). This segregation of space and time is didactic. Harvey reminds us that "the when and where of different kinds of social activity...convey clear social messages" (1990: 419). The clear message taken from the 'when and where' of education is that the appropriate time and location for learning is in the

\footnotetext{
${ }^{4}$ See Collins (2009) for a relatively recent review of this literature.

${ }^{5}$ Importantly, students have agency and actively resist education's role in social reproduction (Weis 1990; Willis 1977).

${ }^{6}$ To be sure, there are non-formal educational spaces whose environment embodies a pedagogical value. Learning at these non-formal sites, such as historic monuments or nature centers, constitutes "field trips" and in most traditional education is the exception and not the rule.
} 
school. A corollary of this is that knowledge is not produced at home. Knowledge is only produced in the classroom, and not in the wider cultural landscape. A dialectical approach based in the concept of timegeography illuminates how school's division of space and time reproduces society.

Time-geography presumes that every action has spatial and temporal attributes (Dodghson 2008; Hallin 1991). The concepts of "path" and "project" link time-geography and social reproduction together. As Pred (1981) describes these ideas, "an individual's biography, whether at a daily scale or as a lifetime, can be charted as an unbroken, continuous path through time space" (p.9, emphasis added). Building on this, the concept of "a project consists of the entire series of simple or complex tasks necessary to the completion of any intention-inspired or goal oriented behavior" (ibid: p.10). Pred argues that the "details of social reproduction, individual socialization, and structuration are constantly spelled out by the intersection of particular individual paths with institutional projects occurring at specific temporal and spatial locations" (Pred 1981: 10). Social reproduction is a dialectic comprised of external (corporeal action) and internal (mental activity and intention) elements. As an individual's life path intersects with particular institutional projects, such as education (ibid p.10), her mental experiences and practical knowledge are shaped, as is her desire to participate in particular institutional projects. In the language of time-geography, a school's institutional project, which consists in part of the strict delineation of time and space, molds the path of individuals, and reproduces society. If the definition of space and time is crucial to how education socially reproduces material relations, than political ecologists should ask, an adapted version of Harvey's question, "What would the space and time of a socialist or ecologically responsible society (school) look like?" (p.432, italics added). One answer lies in recognizing that schools are hybridized exemplars of socionature.

Schools are hybrid because they are comprised of social processes that are interrelated with, and do not operate separately from, ecological conditions. Schools cannot be separated from the environment they exist in and which they transform. From a materialist perspective this makes sense (Benton 1996; Foster 2000; Grundman 1991), as "nature is an integral part of the metabolism of social life. Social relations operate in and through metabolizing the natural environment, which, in turn, transforms both society and nature and produces altered or new sociocultural forms" (Swyngedouw 1996: 446). As opposed to traditional Marxist perspectives that arguably reify a division between the natural and social worlds (Althusser 1965), Swyngedouw (1996) builds upon Neil Smith's (1984; 1996) work to argue that

...nature is an integral part of the process of production, or in other words, that society and nature are integral to each other and produce permanencies (or thing-like moments) in their unity....socionature itself is a historical-geographical process (and therefore time/placespecific). It insists on the inseparability of society and nature and maintains the unity of socionature as a process (Smith 1996: 446).

Schools can be thought of as permanences (Harvey 1996), cyborgs (Haraway 1991), and quasiobjects (Latour 1993). They are the product of historical-geographical processes that metabolize the environment, creating social relations, and ensuring the inseparability of society and nature. Similar to cities, there is neither anything purely social or natural about schools, nor anything a-social or a-natural. Schools are inherently hybrid socio-natural 'things' that are constituted by their own conflicts, tensions, and contradictions (Swyngedouw 1996).

At the grassroots level, schools are being restructured along these hybrid lines. The school is transformed to valorize the cultural landscape as a space-time of knowledge production. Students become knowledge producers who critically reflect upon their reality, and become agents of social change (Freire 1973a, b; Freire and Faundez 1989; Giroux 1996; McClaren and da Silva 1993). The MST is transforming schools, helping students develop new forms of material production, conceptions of nature, and engagements with political economic systems (Meek 2015 a, b). 


\section{Contesting the concentration of land and knowledge}

The Landless Workers' Movement (MST) is the largest agrarian reform social movement in Brazil and seeks to redress Brazil's historical concentration of land. ${ }^{7}$ The MST's members occupy what they perceive as unused agricultural land in order to pressure the government to take that land and create a community, known as a settlement (Wright and Wolford 2003). This tactic of land occupation has historically worked well for the movement in its thirty-year history, because the Brazilian constitution stipulates that if land is not being used in a socially productive manner it can be redistributed by the government (Branford and Rocha 2002; Ondetti 2008; Wolford 2010). ${ }^{8}$

The MST works to democratize access to knowledge as part of their struggle for land redistribution. As an MST educator, interviewed by Diniz-Pereira (2005), remarked: "Knowledge has been very concentrated... It is easier to knock down a latifundium fence than to overcome the invisible fence around knowledge...For instance, the "educational fence" is very hard to knock down" (p.6). In disassembling the fence around knowledge, the MST prioritizes creating education opportunities in its encampments and settlements. As soon as MST members occupy land and form an encampment, they create a rudimentary school, known as an itinerant school (escola itinerante) (Camini 2009). If its members are successful in pressuring the state to create a formal settlement, the MST members will pressure the state for resources to build a quality municipal school.

The schools in MST encampments and settlements are frequently based on critical pedagogy. The principles of conscientization and praxis, which are derived from Brazilian pedagogue Paulo Freire, ground the MST's pedagogy. Conscientization is a process of learning to perceive social, economic, and political contradictions, and to take action against that oppression. Praxis is the action and reflection on the world in order to change it (Freire 1973; Radonic and Kelly-Richards 2015). One way the MST emphasizes the links between conscientization and praxis is that school curricula should arise organically out of, and deal explicitly with, the problems that students identify in their settlements.

The MST recognizes the pivotal importance of local knowledge in its pedagogy. The MST's cubagem da terra (volume of land) approach, for example, synthesizes rural conceptions of land measurement into mathematics and geometry courses (Knjinik's 1997, 2002). The MST's valorization of alternative knowledge tracks larger trends in political ecology, and social science more broadly, towards recognizing the importance of traditional ecological knowledge (Agrawal 2002; Brosius 1997; Nygren 1998; Rhoades and Nazarea 1998; Sillitoe 1998; Vandermeer and Perfecto 2013).

The MST is widely known for its critique of industrial agriculture and mobilization behind agroecology as a more sustainable option (Rosset and Matinez-Torres 2012). Agroecology is a movement, science, and set of practices that revolve around the redesign of agricultural systems grounded in ecological principles (Gliessman 2006; Wezel et al. 2009). In the early 1990s, the MST began shifting away from its original Cuban and Soviet-influenced approach to large-scale collective agriculture and towards family farming (Toledo 2002; Barcellos 2009). As part of this move, the MST began debating the importance of agroecology within the movement. This debate culminated in 2005 at the MST's national congress during which 11,000 members formally ratified agroecology as the agricultural basis for the movement (Altieri and Toledo 2011).

\footnotetext{
${ }^{7}$ The MST's origination is traditionally explained as related to three factors. First, there was a common social grievance for land. Second, various organizations, particularly those involved with the Catholic Church, provided institutional resources (Jenkins 1983; McCarthy and Zald 1977). Third, a political opportunity for mobilization opened alongside the fall of the Brazilian dictatorship (Tarrow 1998). While this "genesis story" explains many macro-level processes, Wolford (2003) argues it is not attuned to the complex politics of place, and does not account for important questions, such as who joined the movement, and what were their motivations. Through multi-sited ethnographic research in the country's south and northeast, Wolford (2004) found that rationales for resistance were grounded in "spatial imaginaries" or particular understandings of space, such as notions of private property, which shape social life.

${ }^{8}$ The MST's approach to land reform is best described as direct action land reform (DALR). While this tactic is frequently successful, an alternative form of land reform based in neoliberal principles, known as market-led agrarian reform (MLAR) is increasingly serving as an impediment to the MST's mobilizations (Borras 2003; Green 2000; Wolford 2005)
} 
The MST has integrated agroecology into its education programs in various ways. Through its membership in the larger transnational peasant movement known as La Via Campesina, the MST has created a variety of agroeclogical schools throughout Brazil (Meek 2015a). The MST has been able to scale up the effect of these schools by creating partnerships with activist university professors and creating new certificate and degree programs for students from agrarian reform settlements (Meek 2015b).

The MST is trying to expand agroecological education at a larger scale through the national movement for Educação do Campo. ${ }^{9}$ The Educação do Campo movement holds that traditional rural schools are not relevant to the lived realities of agrarian reform students (Munarim 2008). Rural schools frequently debase rural areas, forms of knowledge, and the lived realities of rural students, while valorizing urban areas, and preparing students to be urban professionals (Plank 1987, 1996; Soares 2004). One alternative way that Educação do Campo has sought to make education relevant to rural realities is through basing many of its programs around what is known as an alternating pedagogy (pedagogia de alternância), where students spend alternating periods of time in their home and school communities (Trinidade and Vendramini 2011). The alternating pedagogy is grounded in the dual recognition that rural youth play an indispensable agricultural role in their families during harvesting, sowing, and other parts of the local agricultural calendar, and that this experience has pedagogical value (Gnoatto et al. 2006; Ribeiro 2008). Through labor, students engage in informal learning, incorporating knowledge and skills from their parents, neighbors, and larger community. ${ }^{10}$ From a political ecology of education perspective, at the core of the alternating pedagogy is the recognition that educational space-time is not solitary, occurring only in a traditional school, but rather hybrid and constituted through its relation to land management and forms of traditional knowledge gained in rural communities.

An alternative view of knowledge production defines the approach to education within the MST and the larger Educação do Campo movement. From this perspective, knowledge production is not exclusive to experts, but is decentralized and occurs through the everyday individual and collective reflection on reality. This valorization of local knowledge is explicitly political. As Rosaldo, a university educator associated with the MST told me, "Educação do Campo is both a political and epistemological movement; through the partnerships between the social movements and university we end up developing new pedagogical principles." 11 New pedagogical principles, such as the alternating pedagogy, result in education being a hybrid process that addresses inherently spatiotemporal epistemological. Rosaldo continued, indicating that:

The first step in developing these new pedagogical principles is to remove the hierarchy that comes from the perspective of Western knowledge. We need to not debase the knowledge produced through experience. Don't minimize the importance of the popular struggles, as forms of knowledge production, and pedagogical invention. The first step is to criticize this epistemology that makes us academics, and this hierarchical epistemology that obscures other subjects, and enters into the social life of knowledge. We need to emphasize that knowledge is not created from a distance, but instead it is produced through dialogue, through the intentionality of various subjects, through informal knowledge, which has its own traditions, its own history. As a first principle, we can call this interconhecimento, which is the idea is that a course isn't just a location for the development of academic knowledge, but a place for the convergence of experiences. ${ }^{12}$

Prioritizing interconhecimento recognizes that schools and their courses are inherently hybrid. They are synthetic space-times produced by integrating traditional academic knowledge with the tacit

\footnotetext{
${ }^{9}$ Educação do Campo can be translated as rural education, but its meaning is more nuanced, indicating that forms of education are developed in rural areas, by rural people, and relevant to the realities of rural life. Educação do Campo is a national level education reform movement, pedagogical ideology, and set of pedagogical practices. When capitalized herein, it refers to the national movement; otherwise it connotes the ideology and practices.

${ }^{10}$ The alternating pedagogy pre-dates the Educação do Campo movement. It was developed in France in the 1930s, and brought to Brazil as part of the Casas Familias Rurais movement in Brazil (See Gnoatto et al. 2006).

${ }^{11}$ Interview with author on August $12^{\text {th }}, 2012$.

${ }^{12}$ Interview with author on August $12^{\text {th }}, 2012$.
} 
forms of knowledge gained through labor, conversation, and participation in movement activities. Part of the MST's effort to tear down the fence around knowledge is restructuring schools to validate interconhecimento. An institutional document known as the political pedagogical project (PPP) is a central way of valorizing alternative space-times, and resulting forms of knowledge production.

\section{The ongoing struggle for rural education}

The Federal Institute of Pará, Rural Campus of Marabá (IFPA-CRMB) is the product of educational activism. The history of the origination of the campus is exemplary of the long process of micro and macro politics involved in co-production. Knowledge is not created in a vacuum, but in particular centers that are themselves the product of political trajectories. Uncovering the genealogy of an educational institution highlights the ideological framework through which knowledge is produced.

The history of the IFPA-CRMB is characterized by the actions of social movements and institutional activists. During the 1990s, professors from the Federal University of Pará-Marabá campus (UFPA) who were aligned with the region's social movements became involved in helping create environmental education opportunities for rural farmers. This partnership created two educational institutions: an environmental education center known as the Agro-Environmental Center of Tocantins (CAT), and the Family Agricultural School of Marabá (EFA). These two institutions are notable from a co-production standpoint because they are where farmer demands for alternative knowledge production pathways coalesced. In the early 2000s, this partnership between institutional and social movement activists launched a dialogue with the Secretary of Professional and Technological Education about the need for additional education opportunities at the high-school level. In 2003, these groups began to explore the possibility of creating a new school. Marabá was included in the new government plan for the creation of a technological institute system when the newly elected Lula government promised to expand the professional and technological education system. On October $25^{\text {th }}$ 2007, Law 11.534 formally created the Federal Agrotechnical school of Marabá. As a result of the MST's position in the Educação do Campo movement, the MST's 26 de Março settlement was chosen as the site of IFPA-CRMB campus (Figure 1). However, this new school existed only in name, and was delayed in being built. The MST and other social movements needed to pressure the government to construct the IFPA-CRMB.

IFPA-CRMB teachers and students were forced to engage in continued activism for the campus to be completed. The school's vocational high-school program in agroecology and ranching formally began in 2009, but construction on the school had barely started. Without a school, the classes began to meet in a variety of social movement spaces, including an inter-movement organizing space known as Cabanagem, and the MST's Florestan Fernandes National Training School-Amazônia branch. Progress on building the campus was moving very slowly because several of the contractors were embezzling money. The IFPACRMB professors and students decided to take their classes to the half-finished campus as a form of protest. As one student told me; "we came here to where they were building the campus, because if we're here, the process of construction could be accelerated, it can go faster, because we're here and we can see what's going on, we can direct our demands." The legal creation of the IFPA system, the activism that resulted in both its siting in an MST settlement, and the ultimate construction of the IFPA-CRMB campus are exemplary of how both micro and macro-politics are intertwined with the creation of educational spaces. Through an analysis of the PPP I will show how the explicitly political nature of education's spatiotemporal context structures the knowledge produced through student research, its dissemination into a web of rural student communities, and its effects on farmers' understandings of agroecology as a science. The IFPA-CRMB's political and pedagogical project document (projeto político pedagógico or PPP) is central to the school's effort to be a site of alternative environmental knowledge co-production. ${ }^{13}$ Schools throughout Brazil are capable of creating a PPP. This document is non-binding, and is not required by law. It is a voluntary plan that highlights the school's larger ideological grounding, objectives, principles, and strategies for being an instrument of social transformation. The PPP is the product of a conscious

\footnotetext{
${ }^{13}$ An exact translation of projeto politico pedagógico into 'political and pedagogical project' loses some of the phrase's larger meaning. Project in this context has the larger significance of an overarching objective, as in "the project of social transformation."
} 
collective process, which will vary from school to school, but can include teachers, administrators, parents, and social movement leaders.

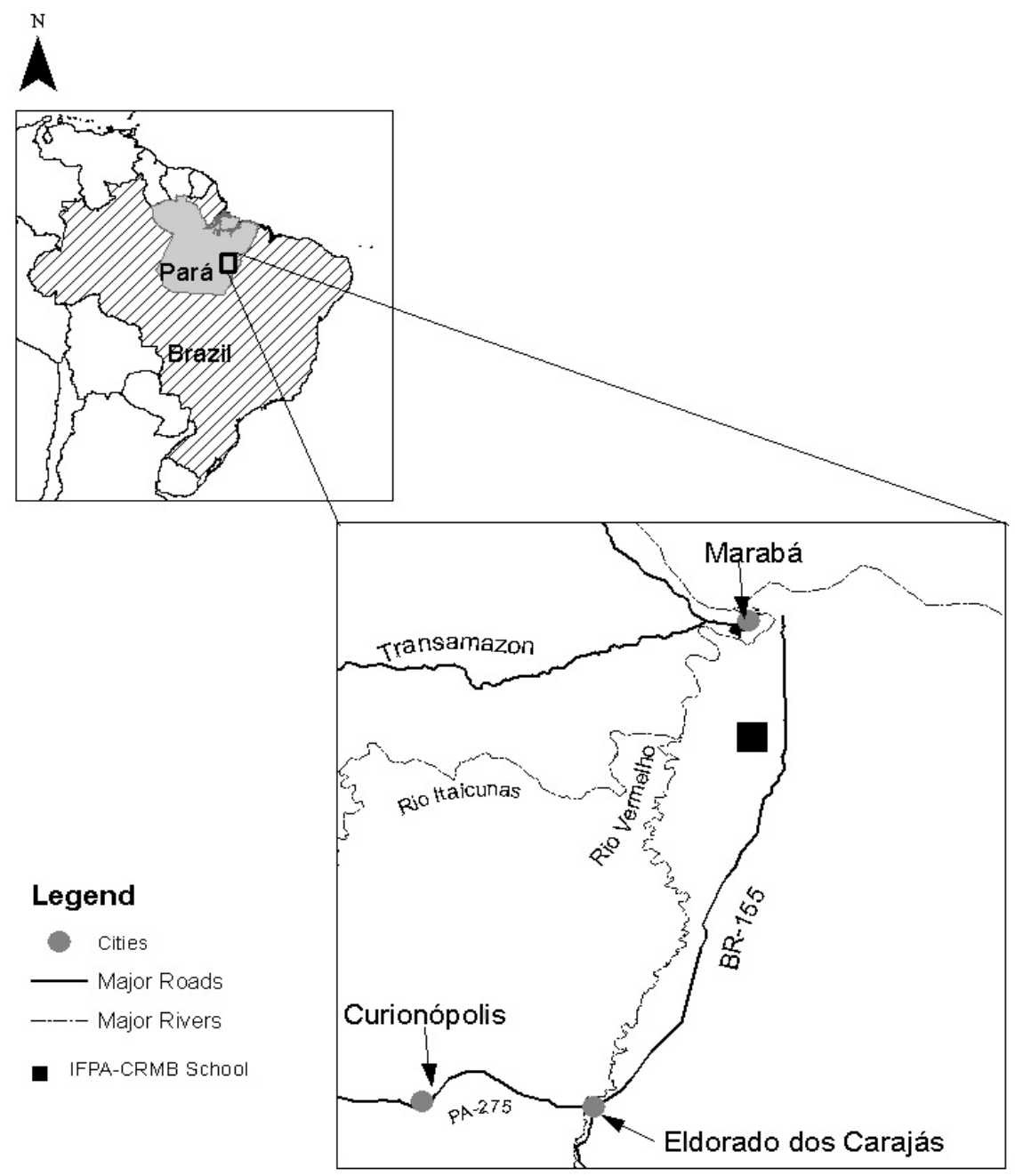

Figure 1: Map showing location of IFPA-CRMB School. Source: David Meek

An analysis of the phrase projeto político pedagógico provides insights into this document's potential for social and environmental transformation. It is defined as a 'project' because it visualizes a new horizon for education, and seeks to explicitly move the school, students, and faculty in that direction. This project is 'political,' because it is grounded in a particular population's sociopolitical reality and their demands. As Veiga, a Brazilian education scholar of PPPs writes, "It is political in the sense of commitment to the training of citizens for a type of society" (2005: 15). The PPP is political, because it seeks to reproduce an alternative vision of society. It is pedagogical because it defines the educational actions and characteristics of the school necessary to achieve its particular proposals.

The PPP defines the "identity" of the school. This identity consists of a thematic focus, pedagogical practices, and the school's relationship with the particular communities it serves. The identity of the school is central to exploring how the ideological basis of the institution influences the co-production of particular forms of knowledge, and how the school will create itself as an instrument of sociopolitical and environmental change. As the next section will demonstrate, the IFPA-CRMB chose to center itself on a critical understanding of the linkages between political economy, livelihoods and landscape change. 
The process through which the PPP is defined is pivotal to the ultimate identity of the school. A collective dialogue that took place in large part through the Regional Forum of Educação do Campo (Forum Regional do Educação do Campo or FREC) was directly responsible for the IFPA-CRMB's PPP (Meek 2015a). ${ }^{14}$ FREC is a network of diverse actors, including rural peasants, indigenous communities, teachers, educational activists, and public institutions that are committed to creating a system of educação do campo. ${ }^{15}$ FREC's main goal is to facilitate the construction of collective projects that will serve as reference points for public policies. By helping to guide policy, FREC seeks to ensure that the state fulfills its duty to develop educação do campo in the region. One of the principal activities of FREC are their (usually) biannual regional conferences. These multi-day events engage hundreds of stakeholders in thematic dialogues around priority projects, such as discussing and developing the IFPA-CRMB PPP. FREC conferences occurred in southeastern Pará in 2001, 2005, 2007, 2009, and 2011.

These conferences, in particular the 2007 conference, whose theme was "Curriculum, public policy, and Educação do Campo," were spaces where prolonged dialogue between various social actors led to the foundational principles of the IFPA-CRMB PPP. One of these principles was the explicit acknowledgement of the importance of regional context, which participants described as "...two competing visions of rural areas that are incompatible: that of industrial agriculture and small-scale farming" (IFPA-CRMB 2010: 4). In counterpoint, FREC participants agreed that rural peasants and indigenous communities needed a school to serve as a tool for environmental sustainability. FREC participants also noted the limited options for professional technical training for rural students. They did not see the existing training as relevant to the reality of peasant and indigenous communities, because it is firmly based in the agroindustrial technological model, "which seeks the extreme homogenization of local agroecosystems, searching for making artificial ones through chemical inputs, and industrial mechanization" (FREC 2011: 30). FREC participants recognized that the type of knowledge produced and disseminated in schools is closely coupled to the type of social landscape that is produced. To transform the social landscape, one needs to transform educational institutions to be based in endogenous forms of knowledge and land management.

FREC participants were integral actors in defining the IFPA-CRMB's focus on the co-production of environmental knowledge. One of their primary demands was the need to solidify a new regional science of agroecology, which would help transform the school's role in re-producing the social landscape. This Eastern Amazonian agroecology would be specific to the region, although it would draw on general agroecological principles that have been developed at national and international levels. It would be created at the intersection of academic and popular knowledge amassed from small family farmers and indigenous organizations. The desire for this 'local science of agroecology' is exemplary of how knowing nature is intricately caught up with the construction of the social landscape. A grassroots recognition emerged from the FREC that the implicit curriculum in the state's model of education is not relevant to peasant and indigenous reality, but instead seeks to prepare students in an industrial agricultural model. By contrast, the FREC conference participants were able to articulate a curricular model that would advance new forms of regional agroecological knowledge, linking the co-production of agroecological knowledge with the social reproduction of an alternative vision of society. In setting the guiding principles of the PPP, FREC participants sought to create a school that would mediate the intertwined processes of the social reproduction of environment-society interrelations, and the co-production of environmental knowledge

\section{The political pedagogical project and the transformation of school socionature}

In the introduction of the PPP, the FREC discourse and guiding principles are clear. The introductory section indicates that the PPP is the product of a collective dialogue between educational activists, social movements, indigenous communities, and state officials. The objectives of the PPP were determined by discussion between professors, teachers, students, parents, and community leaders. The PPP is guided by an understanding of two visions of rural space: one of capital, and the other of family

\footnotetext{
${ }^{14}$ While the actual PPP document was written and edited at separate occasions by a combination of IFPA educators, administrators, and social movement activists the major principles and topics that comprise the PPP were largely developed at the various FRECs.

${ }^{15}$ There are various FRECs in Brazil that are regionally specific. In this article, FREC refers to the FREC in southeastern Pará state.
} 
farming as a counter-hegemonic force. The PPP sees itself as contributing to this process of resistance by working with students to develop a place-based model of agroecology that is relevant to Amazonia and is the product of hybridized knowledge. This is a model that attempts to not reify conceptions of knowledge as purely academic, but rather valorizes and draws upon students' life experiences as pedagogical elements. This discussion of hybrid knowledge is tied to its larger vision of transforming social reproduction.

The school sees itself in "counterpoint to the neoliberal model that generates inequality and social exclusion" (IFPA-CRMB 2011: 5). The introduction to the document situates the school as responsible for the development of a critical citizenry that is capable of understanding the social, economic, and political contexts of their home community and its relation to the state. The school is not content to simply reproduce the social-economic reality into which it is inserted. Rather, the objective is to train students to "organize their territories according to the reproduction of their existence", contributing to family subsistence, community life, and the larger sustainability of southeastern Pará (IFPA-CRMB 2011: 21). It seeks to achieve this objective by training students in regional agroecological practices that are enriching in both a social and environmental context, such as agroforestry, agroextractivism, and cottage-industry production. It will reproduce a novel vision of society by stimulating cooperative working relationshipsencouraging cooperative initiatives, workers' associations, and solidarity economies (IFPA-CRMB 2011: 21). The relation between the development of a regional agroecology and these new structures of material production epitomizes the IFPA-CRMB's role in co-production. Through its production of a regional science the school helps to produce new forms of social organization. The production of regional agroecological knowledge is directly influenced by the school's ideological commitments and students' lived realities. The creation of science cannot be separated from daily reality; the two are "integrated instead as indispensable elements in the process of societal evolution" (Jasanoff 2004: 17).

The PPP proceeds with a regional context section that reads like a treatise in political ecology. It situates the school's origination as beginning with national development projects that opened up the Amazon through road building projects (Branford and Glock 1985; Foweraker 1981). The projects, the PPP argues, further entrenched agrarian inequities in terms of consolidation of land, which led to largescale land violence, including assassination and torture (Simmons 2004; Simmons et al. 2007). As part of this oppression, large-scale farmers and mining companies gained more privilege and power. Family farmers remain important social, political, environmental, and agricultural actors despite these public policies and economic incentives differentially focused on industry. The PPP indicates they resisted the hegemonic narrative of technological progress and development, instead emphasizing the importance of diversified production (Campos and Nepstad 2006). These peasant, proletarian, and indigenous communities have struggled to maintain diversified production systems involving subsistence agriculture, agroforestry, small-scale cattle farming, and timber and non-timber forest extraction (Martinez-Torres and Rosset 2014).

Against this analysis of the tight linkages between political economy and agrarian landscape change, the PPP regional context section then describes how the school is the product of a 'process' launched by social movements to achieve agrarian reform. This process has resulted in the creation of more than 500 settlements in the region, providing access to land and the opportunity for diversified production to more than 80,000 families. The school contributes to the national push for agrarian reform by training students to be professionals who can advance the demands of family farmers. It bemoans that the importance of family farming is decreasing regionally, as subsistence plots and agroforestry are increasingly converted to cattle pasture. This is related to the historical dominance of the cattle industry and the absence of public policies that favor diversification. The school seeks to help reverse this shift to monoculture cattle production by emphasizing agroecological systems that include subsistence production, agroforestry, and cattle production.

Throughout these contextual sections in the PPP, the interrelations between land management, educational opportunities, power, and resistance are underscored continuously. The school originated from a history of educational activism that sought to redress environmental degradation and rural residents' lack of educational opportunities for training in sustainable agriculture. As part of the larger Educação do Campo movement, activists banded together to provide environmental education opportunities at various levels for rural residents who were living in conditions of environmental and educational injustice. From a 
political ecology of education perspective, the school's genesis story narrates the importance of partnerships between movement and institutional activists around the politics of environmental knowledge.

The regional context section of the PPP ends by positioning the school as a response to the ongoing necessity for public policies that guarantee the rights of rural citizens to 'quality education.' Such quality education is endogenous to rural communities, which themselves define the pedagogical content and structure. The regional context section concludes by emphasizing that valorizing rural knowledge is key to advancing endogenous education and redressing historical inequalities in rural education. The pedagogical methods for achieving this are then subsequently described in detail.

The remainder of the PPP is the pedagogical proposal that articulates the ways in which the school will valorize hybrid forms of knowledge, support the development of a regional agroecology, and integrate culture as a pedagogical element. Central to this pedagogical proposal is reorganizing the curriculum away from an urban-centric model. Students will instead, "...explore the existing modes of agricultural production, and realize the value of a new mode of production, which is agroecological, and is part of a scientific approach to food security and environmental sustainability" (IFPA-CRMB 2011: 32). These linkages between exploring existing modes of production, and the valuation of agroecology as a "new mode of production", underscore how co-produced knowledge plays a role in the reproduction of an alternative vision of society.

A central part of restructuring the curriculum is transforming traditional conceptions of educational space and time. The PPP initially deals with space and time in a broad way that emphasizes the pedagogical value of culture. "We need to organize the educational spaces and times in a way that respects the lifestyle of the rural communities, respects their culture and seeks to contribute to the elevation of their self-esteem" (IFPA-CRMB 2011: 22). The pedagogical proposal calls for rethinking where education takes place, positioning the school as interlinked with other educational spaces-specifically those that involve political organizing and cooperative production.

The school year's basis in an alternating pedagogy is the specific way it valorizes alternative times and spaces of education. As part of the alternating pedagogy, students spend alternating periods of time in their home and school communities. In Brazil, the legal system guarantees the right for schools to organize themselves according to the reality specific to particular rural areas. In articles 23 and 28 of Law 9.394/96 (Lei de Diretrizes e Bases da Educacao Nacional 1996-LDB \#9394/1996) there is a provision for a regional school calendar which tracks the agricultural calendar and is based on the combination of seasonal climatic trends and the sociocultural requirements of the rural people. As the pedagogical proposal argues, having the ability to reorganize the curriculum ensures the:

...possibility of developing a process that will integrate school/scientific knowledge with popular knowledge and valorize the knowledge that the youth already carry with them, developed through their individual and collective life paths, through the family and community, which is an expression of their values and culture (IFPA-CRMB 2011: 35).

The division of time is set to be $1 / 3$ in the home community and $2 / 3$ in the school. This ratio enables:

...the integrated reflection about social-cultural experiences, participation in community political life, agricultural production, and the critical reflection upon labor, promoting sustainable production and the development of a new transformative relation with nature that will be equilibrial, creating the conditions necessary for the sustenance and continued existence of the family (IFPA-CRMB 2011: 37).

The reorganization of time and space is closely linked to affirming the hybrid nature of the school and the co-production of knowledge. Reorganizing time around an alternating pedagogy plays an important role in hybridizing of the school through a "...new transformative relation with nature that will 
be equilibrial," and social reproduction, which creates the "...conditions necessary for the sustenance and continued existence of the family."

The alternating pedagogy consists of creating a curriculum that intentionally integrates different modes, times, and spaces of knowledge construction. The central tenet of using the alternating pedagogy as a pedagogical principle is that 'research on reality' (pesquisa da realidade) is the starting point for the educational process (IFPA-CRMB 2011: 37). At the IFPA-CRMB, research positions students as hybrid knowledge producers, where they synthesize their previous life experiences with the critical reflections of their field-based research. Questions about time-geography are integral to the school's politics of environmental knowledge production. As one instructor emphasized to me:

We need to think about the relation between the times and spaces of school and home periods. The alternating pedagogy is just this, that you need to take research with its roots, you need to think about the origins, the places that the students come from. Throughout the course there are times built in to allow students to problematize their realities. This is the core of the alternating pedagogy: we alternate times and spaces to construct knowledge that come closer to approximating the experiences of the subjects. ${ }^{16}$

The community time-space is understood as the spatiotemporal context in which rural students learn through the forms of labor and activities that take place in the family, community, and political context. It is a time-space that enables experience, research, and experimentation-allowing for the hybridization of school and popular knowledge.

Encouraging student research is one of the main objectives of the IFPA-CRMB. This research consists of students uncovering the historical, economic, cultural, educational environmental, and political histories of their communities. ${ }^{17}$ The PPP describes the 'investigation of reality' as a 'pedagogical strategy', which directs "...research to focus on the environmental problems, the social and productive relations they're involved with, the culture that they are embedded in, the organizational strategies within their communities, using as tools diverse forms of knowledge and scientific methodologies" (IFPA-CRMB 2011: 36). These strategies are developed to "...provoke the students to individually and collectively investigate reality, to experiment with forms of social and productive organization, and to develop new projects" (IFPA-CRMB 2011: 36). The students' research strategies are dually based in co-production and social reproduction. Students investigate environmental and social contradictions and in doing so leverage "...diverse forms of knowledge and scientific methodologies" to develop a regional agroecology that will facilitate "new forms of social and productive organization." From a political ecology of education perspective, the spatiotemporal contexts where education occurs matter because the histories of environmental exploitation, resistance, and agricultural experimentation that are constitutive of the cultural landscape serve as texts which students uncover in their research.

The space-time of school is one of intentional distance from daily reality. This distance is created so that students can reflect upon their reality, developing new forms of knowledge that can be used as tools for transforming that reality at both a micro and macro level. Although the PPP positions the school time-space as a "distance" from that of the community, as the proposal goes on, it becomes clear that the "distance" is one through which the school itself is produced as a hybrid time-space.

The pedagogical proposal highlights several methods for ensuring continuity of education between the home and school communities. The first is the "Study, Research, and Work Plan," which students and teachers collectively develop. The plan, which is individualized to the student, specifies a research or experiential education activity, such as an internship, in which the student will reflect on the contradictions of their reality and real production demands in the region. Through these tailored activities, students gain experience with research methods and become active subjects in the construction of knowledge.

\footnotetext{
${ }^{16}$ Interview with author on June $12^{\text {th }} 2012$.

${ }^{17}$ The information students collect is instrumental to the content the school's space-time covers (see below).
} 
The second pedagogical method of keeping the community and school space-time in dialogue are group discussion (coloção em comum) activities. When students return to school, educational space-times are created where students will present findings from their community research and engage their cohort in a larger debate concerning the findings. During these sessions the instructors do not intervene, but simply moderate the debate; the teachers' role is to draw upon the students' research to structure the contents of future classes. The themes that the professors extract are the elements of the debate that are most polemical. The professors take these elements as Freirean 'generative themes,' which are "...codifications of complex experiences in the lives of participants. They have political significance and are likely to generate considerable dialogue towards action" (Souto-Manning 2010: 36). The generative themes are then taken by the professors and used as part of a feedback loop, informing future course modules and activities. The CRMB uses this feedback loop between students research findings, debates, generative themes, and future course work to ensure a critical and creative engagement with scientific knowledge which will enable "...moving beyond the passive consumption and reproduction of ready-made ideas and already crystalized knowledge" (IFPA-CRMB 2011: 39). These group discussion activities make visible the school's inherent hybridity by purposefully valorizing the interconnections between the space-time of home and school. They also make conscious the school's role in co-production of environmental knowledge by "...moving beyond passive consumption" and engaging students as active knowledge producers.

The third pedagogical method for ensuring educational continuity seeks to bring new knowledge back into the community. The CRMB holds mini-courses and workshops for community members that are related to particular courses at the school. The generative themes from the classroom serve as springboards for larger community discussions and the origination of new questions about local realities, as well as new theoretical questions to be researched in the future. These community events serve to "legitimize the social process of education" (IFPA-CRMB 2011: 37), or the inherently social process through which knowledge is produced. Bringing knowledge and debates from school back into the community is one way that education functions as alternative social reproduction, enabling a dialogue about new forms of environmental knowledge and their implications for emerging forms of social organization.

The IRPA-CRMB pedagogical proposal emphasizes the importance of 'social productive experimentation' as a means to creating a regional agroecology and advancing larger-scale agroecological transition. This agroecological transition is a shift from mechanized, input-reliant, industrial monocultures to polycultures based on ecological design. 'Socially-productive experimentation' is described in the PPP as a pedagogical strategy. It occurs in the daily experiences and social relations of agricultural experiments that promote learning through solidarity, cooperation, and justice and encourage social and ecological responsibility, the reinvention of labor relations, and the sustainable use of natural resources. The PPP argues that agroecological experimentation at the IFPA-CRMB will serve as a reference point for the development of new forms of agroecological land management. The PPP indicates that this engagement with agroecological experimentation will serve as a reference point for developing a new locally appropriate agroecological science which will later be taken up within rural communities. The IFPA-CRMB's agroecological experimentation exemplifies how co-production and social reproduction intersect. The production of agroecological knowledge will serve as a reference point for the restructuring of rural communities. The linkages between the co-production of environmental knowledge and social reproduction occur by valorizing alternative time-spaces for education which elevates the hybrid nature of the school.

The PPP sets out various ways in which the IFPA-CRMB will advance agroecological experimentation. The first are the experimental production units, which are thematic student group projects. These include apiculture, psiculture, aviaries, horticulture, biogas production, and the creation of artisanal jewelry. Other forms of agroecological experimentation take place when students are in their home community. Students work with farmers to systematize agroecological innovations, for example, documenting local approaches to pest control. Working with farmers in this context serves to deepen their knowledge base, synthesizing traditional and academic technical knowledge. Lastly, students are expected to become involved in, and lead, collective agroecological actions in their community, such as community gardens, reforestation initiatives, and heirloom seed banks. Cumulatively, these initiatives are considered a 
type of 'synthesis project' that will systematize the daily experiences of students and their hybridized knowledge; this systematization is intended to lead to the development of viable pathways to improved rural life. The co-production of agroecological knowledge through pedagogical experimentation serves as a form of alternative social reproduction that transforms the social landscape. The hybrid nature of educational space-times, where academic and traditional knowledge are intertwined, is responsible for structuring how environmental knowledge and alternative forms of social organization are co-produced.

\section{Conclusion}

Schools are not solitary time-spaces. Rather, they are hybrid phenomena that are constructed through a dialogue between spatiotemporal contexts. Schools can play an important role in mediating the intertwined processes of the social reproduction of environment-society interrelations, and the coproduction of environmental knowledge. This article's analysis of the IFPA-CRMB's PPP highlights how the dual processes of knowledge co-production and social reproduction pivot upon a school's conception of space-time. From a political ecology of education perspective, knowledge production is directly influenced by the school's ideology and the history of its political economic landscape. As Jasanoff reminds us, "...the ways in which we understand the world are tied at all points-like the muscles on a skeleton or the springs on a cot frame-to the ways in which we have already chosen to live in it" (Jasanoff 2004: 4). Administrators, instructors, and students of the IFPA-CRMB have chosen to live in the world in a way guided by social and environmental justice concerns. This collective ideology shapes how students come to 'understand the world.' At the IFPA-CRMB students are engaged in the process of developing a regional agroecological science, one forged through hybridization of the school and home community's space-time, and the accompanying traditional and academic forms of knowledge that characterize these spaces. As students engage in agroecological experimentation and devise new forms of cooperative production, "...the workings of science and technology cease to be a thing apart from other forms of social activity, but are integrated instead as indispensable elements in the process of societal evolution" (Jasanoff 2004: 17). Through the process of co-production science and society are constructed. Just as there are no major changes in science without concomitant shifts in the cultural politics of society, so too can changes in political economic systems be brought about through the development of new forms of knowledge. The IFPA-CRMB provides an important example of how a school can both critically educate students to understand the political ecology of their landscape and help them develop methodological and theoretical tools necessary to transform their reality around social and environmental justice concerns. The IFPA-CRMB incorporates the tools of political ecology, including a hybridized conception of environmental knowledge and a critical reflection on the influence of political economy in producing agrarian landscapes, into its curricula. Restructured institutions like the IFPA-CRMB have the power to promulgate alternative conceptions of material relations, forms of social organization, and conceptions of environmental knowledge. Applied political ecologists can draw upon the example of the IFPA-CRMB's PPP to critically discuss with educators, administrators, and students the possibility of incorporating analyses of regional political economy and ecology into school curricula, and expanding the school's spatiotemporal nature to account for hybridized knowledge.

\section{References}

Abu-Lughod, L. 1998. Television and the virtues of education: upper Egyptian encounters with state culture. In N. S. Hopkins and K. Westergaard (eds.) Directions of rural change in Egypt. Cairo: American University Press. Pp 147-165.

Abu-Lughod, L. 2003. Dramas of nationhood: the politics of television in Egypt. Chicago: University of Chicago Press.

Althusser, L. 1965. Pour Marx. Paris: Maspero.

Altieri, M.A. and V.M. Toledo. 2011. The agroecological revolution in Latin America: rescuing nature, ensuring food sovereignty and empowering peasants. Journal of Peasant Studies 38(3): 587-612.

Anderson, B. 1983. Imagined communities: reflections on the origin and spread of nationalism. London: Verso. 
Anyon, J. 1981. Social class and school knowledge. Curriculum Inquiry 11: 3-41.

Apple, M.W. 1979. Ideology and curriculum. London: Routledge \& Kegan Paul.

Apple, M.W., and N. R. King. 1977. What do schools teach? Curriculum Inquiry 6(4): 341-358.

Baker, A.C., et al. 2002. Learning and conversation. In A.C. Baker, P.J. Jensen and D.A. Kolb (eds.) Conversational learning: an experiential approach to knowledge creation. Westport, Conn: Quorum Books. Pp 1-15.

Barcellos, S.B. 2009. A formação discursiva agroecológica do MST: o caso do assentamento Santa RosaRS. Cadernos de Agroecologia 4(1): 2059-2063.

Benton, T. 1996. The greening of Marxism. New York: Guilford Press.

Biersack, A. and J.B. Greenberg (eds.) 2006. Reimagining political ecology. Durham: Duke University Press.

Borras, S.M. 2003. Questioning market-led agrarian reform: experiences from Brazil, Colombia and South Africa. Journal of Agrarian Change 3(3): 367-394.

Bourdieu, P. and J.C. Passeron. 1977. Reproduction in education, society and culture. Beverly Hills, CA: Sage Publications.

Bowles, S. and H. Gintis. 1976. Schooling in capitalist America. New York: Basic Books.

Branford, S. and O. Glock. 1985. The last frontier: fighting over land in the Amazon. Totowa, N.J.: Zed Books.

Branford, S. and J. Rocha. 2002. Cutting the wire: the story of the landless movement in Brazil. London, Latin America Bureau.

Breitenbach, F.V. 2011. A educação do campo no Brasil: uma história que se escreve entre avanços e retrocessos. Espaço Academico 11(121): 116-123.

Brosius, J.P. 1997. Endangered forest, endangered people: environmentalist representations of indigenous knowledge. Human Ecology 25(1): 47-69.

Bryant, R.L. 1997. The political ecology of forestry in Burma: 1824-1994. Honolulu: University of Hawaii Press.

Caldart, R.S. 2001. O MST e a formação dos sem terra: o movimento social como princípio educativo. Estudos Avancados 15(43): 207-224.

Camini, I. 2009. Escola itinerante: na fronteira de uma nova escola. São Paulo: Expressão Popular.

Campos, M.T. and D.C. Nepstad. 2006. Smallholders, the Amazon's new conservationists. Conservation Biology 20(5): 1553-1556.

Carnoy, M. and H. Levin. 1985. Schooling and work in the democratic state. Stanford, CA: Stanford University Press.

Chandler, W.L. 2009. A teacher space or a learner place? reconsidering the classroom environment. International Journal of Learning 16(9): 261-267.

Collins, J. 2009. Social reproduction in classrooms and schools. Annual Review of Anthropology 38: 3348.

Comber, B. and H. Nixon. 2008. Spatial literacies, design texts, and emergent pedagogies in purposeful literacy curriculum. Pedagogies: an International Journal 3: 221-240.

Cox, K.R. 1998. Representation and power in the politics of scale. Political Geography 17(1): 41-44.

Crockenberg, S.B. and B.K. Bryant. 1978. Socialization: the implicit curriculum of learning environments. Journal of Research and Development in Education 12(1): 69-78.

Demerrit, D. 2001. The construction of global warming and the politics of science. Annals of the Association of American Geographers 91(2): 307-337.

Diniz-Pereira, J. E. 2005. Teacher education for social transformation and its links to progressive social movement: the case of the landless workers movement in Brazil. Journal for Critical Education Policy Studies 3(2): 91-123.

Dodgson, R.A. 2008. Geography's place in time. Geografiska Annaler B 90(1): 1-15.

Dudley, H.J. 1977. Implicit curriculum--where values are really taught. Science Teacher 44(3): 30-31. 
Forsyth, T. 2003. Critical political ecology: the politics of environmental science. London: Routledge.

Foster, J.B. 2000. Marx's ecology: materialism and nature. New York: NYU Press.

Foweraker, J. 1981. The struggle for land: a political economy of the pioneer frontier in Brazil from 1930 to the present day. New York, Cambridge University Press.

FREC (Forum Regional do Educação do Campo) 2011. 5 a Conferençia Regional De Educação do Campo do Sul e Sudeste do Pará. Caderno de Textos.

Freire, P. 1973. Pedagogy of the oppressed. New York: Continuum.

Freire, P. 1973. Education for critical consciousness. New York: Seabury Press.

Freire, P. and A. Faundez. 1989. Learning to question: a pedagogy of liberation. New York: Continuum.

Giroux, H.A. 1996. Counternarratives: cultural studies and critical pedagogies in postmodern spaces. New York: Routledge.

Gliessman, S.R. 2006. Agroecology: The ecology of sustainable food systems. Boulder: CRC.

Gnoatto, A.A., et al. (2006). Pedagogia da Alternancia; Uma proposta de educaca e desenvolvimento no campo. XLIV Congresso da Sober. Fortaleza.

Goldman, M.J., P. Nadasdy and M.D. Turner (eds.). 2011. Knowing nature: conversations at the intersection of political ecology and science studies. Chicago: University of Chicago Press.

Goldman, M.J. and M.D. Turner. 2011. Introduction. In Goldman, M.J., P. Nadasdy, and M.D. Turner (eds). Knowing nature: conversations at the intersection of political ecology and science studies. Chicago: University of Chicago Press. Pp 1-14.

Gough, A. and Whitehouse, H. 2003. The "nature" of environmental education research from a feminist poststructuralist standpoint. Canadian Journal of Environmental Education 8: 31-43.

Grundman, R. 1991. Marxism and ecology. Oxford: Clarendon Press.

Hallin, P.O. 1991. New paths for time-geography? Geografiska Annaler B 73B(3): 199-207.

Harraway, D. 1991. Simians, cyborgs and women-the reinvention of nature. London: Free Association Books.

Harvey, D. 1990. Between space and time: reflections on the geographical imagination. Annals of the Association of American Geographers 80(3): 418-434.

Harvey, D. 1996. Justice, nature and the geography of difference. Oxford: Blackwell.

IFPA-CRMB (Federal Institute of Pará-Rural Campus of Marabá) 2010. Projeto Político Pedagógico. Ministério da Educação, Marabá.

Inlay, L. 2003. Values: the implicit curriculum. Educational Leadership 60(6): 69-71.

Jasanoff, S. (ed.). 2004. States of knowledge: the co-production of science and the social order. London: Routledge.

Knijnik, G. 1997. Popular knowledge and academic knowledge in the Brasilian peasants' struggle for land. Educational Action Research 5(3): 501-511.

Knijnik, G. 2002. Curriculum, culture and ethnomathematics: the practices of 'cubagem of wood' in the Brazilian landless movement. Journal of Intercultural Studies 23(2): 149-165

Latour, B. 1993. We have never been modern. London: Harvester Wheatsheaf.

Livingstone, D.W. 2006. Informal learning: conceptual distinctions and preliminary findings. In Z. Bekerman, N.C. Burbules and D. Silberman-Keller (eds.) Learning in places: the informal education Reader. New York: Peter Lang. Pp 203-227.

Marsick, V.J., et al. 2009. Informal and incidental learning in the workplace. In M.C. Smith and N. DeFrates-Densch (eds.) Handbook of research on adult learning and development. Taylor and Francis. Pp 570-601.

McKenzie, M. 2012. Education for y'all: global neoliberalism and the case for a politics of scale in sustainability education policy. Policy Futures in Education 10(2): 165-178.

McLaren, P. and T. da Silva. 1993. Decentering pedagogy: critical literacy, resistance, and the politics of memory. In P. McLaren and P. Leonard (eds.) Paulo Freire: a critical encounter. New York: Routledge. Pp 47-89. 
Meek, D. 2011. The Brazilian landless worker's movement and the war of position: a content analysis of propaganda and collective participation within the Jornal Sem Terra. Studies in the Education of Adults 43(2): 164-180.

Meek, D. 2014. Sustainability education: what's politics got to do with it? Journal of Sustainability Education 7.

Meek, D. 2015a. Towards a political ecology of education: the educational politics of scale in southern Pará, Brazil. Environmental Education Research 21(3): 447-459.

Meek, D. 2015b. Learning as territoriality: The political ecology of education in the Brazilian Landless Workers' Movement. Journal of Peasant Studies 42(6): 1179-1200

Munarim, A. 2008. Trajetória do movimento nacional de educação do campo no Brasil. Educação Jan/Abr: 57-72.

Nespor, J. 2002. Studying the spatialities of schooling. Pedagogy, Culture, and Society. 10(3): 483-491.

Noguera, P.A. 2009. The trouble with black boys:... and other reflections on race, equity, and the future of public education. New York: John Wiley \& Sons.

Nygren, A. 1999. Local knowledge in the environment-development discourse: from dichotomies to situated knowledges. Critique of Anthropology 19(3): 267-288.

Ondetti, G. 2008. Land, protest, and politics: the landless movement and the struggle for agrarian reform in Brazil. University Park: Pennsylvania University Press.

Peet, R. and M.J. Watts 1996. Liberation ecologies: environment, development, social movements. New York, NY: Routledge.

Peluso, N.L. 1992. Rich forests, poor people: resource control, and resistance in Java. Berkeley, CA: University of California Press.

Piro, J. M. 2008. Foucault and the architecture of surveillance: creating regimes of power in schools, shrines, and society. Educational Studies 44: 30-46.

Plank, D. 1987. The expansion of education: a Brazilian case study. Comparative Education Review 31(3): 361-376.

Plank, D.N. 1996. The means of our salvation: public education in Brazil, 1930-1995. Boulder, Colo.: Westview Press.

Pred, A. 1981. Social reproduction and the time-geography of everyday life. Geografiska Annaler B: 5-22.

Radonic L. and S. Kelly-Richards. 2015. Pipes and praxis: a methodological contribution to the urban political ecology of water. Journal of Political Ecology 22: 389-409.

Rhoades, R. E. and V. Nazarea. 1999. Local management of biodiversity in traditional agroecosystems. In W. W. Collins and C. O. Qualset (eds.) Biodiversity in agroecosystems. CRC Press. Pp 215-236.

Ribeiro, M. 2008. Pedagogia da alternância na educação rural/do campo: projetos em disputa. Educação e Pesquisa 34(1): 27-45 English version

Robbins, P. 2004. Political ecology: a critical introduction. Malden, MA: Blackwell.

Rosset, P.M. and M.E. Martinez-Torres. 2012. Rural social movements and agroecology: context, theory, and process. Ecology and Society 17(3): 17.

Martínez-Torres, M.E. and P.M. Rosset. 2014. Diálogo de saberes in La Vía Campesina: food sovereignty and agroecology. Journal of Peasant Studies 41(6): 979-997.

Schmink, M. and C. Wood. 1987. The political ecology of Amazonia. In P. Little, M. Horowitz and A.E. Nyerges (eds.) Lands at risk in the third world. Boulder: Westview press. Pp 38-57.

Simmons, C.S. 2004. The political economy of land conflict in the eastern Brazilian Amazon. Annals of the Association of American Geographers 94: 183-206

Simmons, C.S., R.T. Walker, E.Y. Arima, S.P. Aldrich and M.M. Caldas 2007. The Amazon land war in the south of Pará. Annals of the Association of American Geographers 97(3): 567-592.

Smith, N. 1984. Uneven development: nature, capital, and the production of space. Oxford, Blackwell.

Smith, N. 1992. Geography, difference and the politics of scale. In Doherty J., E. Graham and M. Malek (eds.) Postmodemsm and the social sciences. London: Macmillan. Pp 57-79. 
Smith, N. 1996. The production of nature. In G. Robertson, M. Marsh, L. Tickner et al. (eds.) Futurenatural--nature/science/culture. New York: Routledge. Pp 35-54.

Soares, F. 2004. Quality and equity in basic Brazilian education: facts and possibilities. In C. Brock and S. Schwartzman (eds.) The challenges of education in Brazil. London: Symposium Books. Pp 69-88.

Souto-Manning, M. 2010. Freire, teaching, and learning: culture circles across contexts. New York: Peter Lang.

Swyngedouw, E. 1996. The city as a hybrid: on nature, society and cyborg urbanization. Capitalism Nature Socialism 7(2): 65-80.

Toledo, V.M. 2002. Agroecología, sustentabilidad y reforma agraria: la superioridad de la pequeña producción familiar. Agroecologia e Desenvolvimento Rural Sustentável 32(2): 27-37.

Trindade, G.A. and C.R. Vendramini. 2011. A relação trabalho e educação na pedagogia da alternancia. Revista HISTEDBR On-line 44: 32-46.

Vandermeer, J. and I. Perfecto. 2013. Complex traditions: intersecting theoretical frameworks in agroecological research. Agroecology and Sustainable Food Systems 37: 76-89.

Veiga, I. P. A. 2005. Projeto político-pedagógico da escola. Rio de Janeiro, Papirus Editora.

Weiss, L. 1990. Working class without work: high school students in a de-industrialized economy. New York: Routledge.

Wezel, A., et al. 2009. Agroecology as a science, a movement, and a practice. Agronomy for Sustainable Development 29(4): 503-515.

Willis, L. 1977. Learning to labor: how working class kids get working class jobs. New York: Teachers College Press.

Wolford, W. 2005. Agrarian moral economies and neoliberalism in Brazil: competing worldviews and the state in the struggle for land. Environment and Planning A 37: 241-261.

Wolford, W. 2010. This land is ours now: social mobilization and the meanings of land in Brazil. Durham: Duke University Press.

Wright, A. and W. Wolford. 2003. To inherit the earth: the landless movement and the struggle for a new Brazil. Oakland: Food First!

Zimmerer, K.S. and T.J. Bassett. 2003. Political ecology: an integrative approach to geography and environment-development studies. New York: Guilford Press. 